\title{
TAP FOR BATTLE: PERANCANGAN CASUAL GAME PADA SMARTPHONE ANDROID
}

\author{
Andry Chowanda; Benard H. Prabowo; Glen Iglesias; Marsella Diansari \\ Computer Science Department, School of Computer Science, Binus University \\ Jl. K.H. Syahdan No. 9, Palmerah, Jakarta Barat 11480 \\ achowanda@binus.edu
}

\begin{abstract}
Smartphones have become a necessity. Almost everyone uses a smartphone in a variety of activities. Both young and old are sure to utilize this technology, for a wide range of activities such as doing the work, doing school work or enjoying entertainment. The purpose of this research is to build a casual-action game with war theme. The game is built for Android smartphone that has multi touch screen capability. The research methods used in this research are data collection and analysis method including user analysis with questionnaire. Furthermore, IMSDD method is implemented for game design and development phase including system requirement analysis, system design, system implementation, finally system evaluation. In this research, we conclude that $83.9 \%$ participants enjoyed the game with touch-screen as the game control.
\end{abstract}

Keywords: game, game design, android, touch-screen, IMSDD

\begin{abstract}
ABSTRAK
Smartphone telah menjadi sebuah kebutuhan. Hampir setiap orang menggunakan smartphone dalam berbagai aktivitas. Baik yang muda sampai yang tua pasti memanfaatkan teknologi ini, untuk berbagai macam kegiatan seperti melakukan pekerjaan, melakukan tugas sekolah maupun menikmati hiburan. Tujuan dari penelitian ini adalah pembuatan aplikasi permainan bergenre casual-action, dengan tema perperangan dengan menggunakan teknologi touch-screen dan memanfaatkan teknologi multi-touch pada Android. Metode Penelitian yang digunakan adalah metode pengumpulan data dan analisis data, dimana di dalamnya mencakup metode studi kepustakaan, mengadakan kuesioner, analisa terhadap data dan analisa terhadap permainan sejenis, dan juga metode perancangan aplikasi dengan metode IMSDD, d imana di dalamnya mencakup analisa kebutuhan sistem, pertimbangan desain, implementasi dan evaluasi. Kesimpulan yang didapatkan dari penelitian ini adalah, teknologi touch-screen dapat dimanfaatkan sebagai kontrol utama untuk bermain game dan banyak pengguna (83.9\%) yang tertarik untuk menggunakan teknologi tersebut dalam bermain game.
\end{abstract}

Kata kunci: game, game design, android, touch-screen, IMSDD 


\section{PENDAHULUAN}

Smartphone telah menjadi sebuah kebutuhan bagi hampir seluruh manusia. Hampir setiap orang menggunakan smartphone mereka dalam mengerjakan setiap kegiatan, baik masyarakat muda sampai yang tua pasti memanfaatkan teknologi canggih ini, baik untuk melakukan pekerjaan, pendidikan maupun sebagai sarana hiburan. Padatnya kesibukan dari kegiatan rutinitas, setiap orang membutuhkan hiburan untuk menghilangkan rasa bosan dan penat. Salah satu hiburan yang paling banyak diminati adalah game (Chowanda \& Prasetio, 2012; Chowanda, 2011).

Penelitian di bidang game telah menjadi salah satu topik yang banyak diminati oleh berbagai kalangan (Chowanda \& Prasetio, 2012). Dari kalangan komersial sampai dengan kalangan akademia. Kalangan komersial biasanya berfokus pada bagaimana membuat game play yang dapat menarik para pemain untuk terus memainkannya, sedangkan kalangan akademia berfokus pada bagaimana memanfaatkan game untuk beberapa tujuan seperti terapi, training, dll. Beberapa contoh penelitian game yang berfokus pada game play dilakukan oleh Chowanda (2011), sedangkan penelitian game untuk beberapa tujuan dilakukan oleh Chowanda \& Prasetio (2012); Chowanda A. (2013); Chowanda A. (2011).

Pada era ubiquitous ini, para pecinta game tidak perlu lagi duduk dan diam di depan komputer mereka untuk dapat bermain. Para pecinta game dapat bermain di mana saja melalui smartphone mereka. Setiap smartphone memiliki operating system yang memiliki kelemahan dan kelebihann masing-masing. Menurut penelitian yang dilakukan oleh IDC (lihat Tabel 1), Android masih menguasai pasar ponsel pintar di tahun 2014. Persentase pasar android naik sebanyak 5.8\% dari tahun sebelumnya dan 45\% dari tahun 2011 (IDC, 2014). Melihat adanya kebutuhan serta peluang yang tertera di atas maka perancangan permainan yang bertemakan perperangan pada smartphone Android dilakukan. Game dibuat 2D agar lebih mudah disesuaikan dengan berbagai jenis smartphone berbasis Android dan melihat kesesuaian antara game play dengan grafis.

Tabel 1 Worldwide Smartphone OS Market Share (Share in Unit Shipments) Sumber (IDC, 2014)

\begin{tabular}{cccccc}
\hline Period & Android & iOS & Windows Phone & BB OS & Others \\
\hline Q1 2014 & $81.10 \%$ & $15.20 \%$ & $2.70 \%$ & $0.50 \%$ & $0.60 \%$ \\
Q1 2013 & $75.30 \%$ & $17.10 \%$ & $3.20 \%$ & $2.90 \%$ & $1.50 \%$ \\
Q1 2012 & $59.20 \%$ & $23.00 \%$ & $2.00 \%$ & $6.30 \%$ & $9.50 \%$ \\
Q1 2011 & $36.10 \%$ & $18.30 \%$ & $1.20 \%$ & $13.60 \%$ & $30.80 \%$ \\
\hline
\end{tabular}

Ruang lingkup penelitian ini adalah merancang game play, game art, serta game story pada permainan ini, kemudian merancang sebuah prototype aplikasi untuk platform Android dengan memanfaatkan teknologi multi-touch yang dimiliki Android minimal versi 2.2. Agar game dapat tampil lebih menarik, penelitian ini juga mencakup perancangan Artificial Intelligence yang akan digunakan untuk menggerakkan karakter musuh dengan menggunakan algoritma shortest path.

Tujuan dari penelitian ini menciptakan sebuah aplikasi permainan bertema perang yang dapat dinikmati banyak kalangan yang dapat dimainkan secara mobile oleh pengguna device Android. Sedangkan manfaat dari penelitian ini diharapkan agar game ini dapat menjadi sarana hiburan untuk refreshing serta untuk mengisi waktu luang, serta menambah alternatif aplikasi permainan yang bisa dimainkan pada device dengan sistem operasi Android. 


\section{METODE}

Metode yang digunakan adalah metode pengumpulan data, analisis data, serta perancangan aplikasi yang di mana penelitian ini menggunakan metode IMSDD (Interactive Multimedia System of Design and Development). Perancangan adalah hal yang butuh kreativitas yang tinggi dan tidak dapat diprediksi. Perancang sistem interaktif harus menggabungkan pengetahuan teknis dengan nilai estetika yang dapat menarik perhatian pengguna. Metode untuk rancangan yang memilki kekhasan (Rosson \& Carroll, 2002a; Rosson \& Carroll, 2002b). Siklus dari IMSDD, menurut Dastbaz (2002) mencakup kebutuhan pengguna, pertimbangan desain, implementasi, serta evaluasi.

Metode yang digunakan dalam pengumpulan data dan analisis data mencakup sebagai berikut: (1) Metode Studi Kepustakaan. Pengumpulan data dan informasi dari literatur tertulis seperti buku, artikel, dan tutorial online untuk dijadikan landasan teori atau referensi dalam penyusunan penelitian dan pengembangan aplikasi. Literatur yang dimaksud bisa diperoleh dari beberapa sumber, misalnya dari perpustakaan atau dunia maya. (2) Kuesioner. Melakukan survei berupa kuesioner untuk mencari informasi mengenai kesukaan masyarakat terhadap hal tertentu yang dapat berpengaruh terhadap arah pengembangan aplikasi, seperti jenis atau genre permainan yang diminati, juga mengenai perkembangan penggunaan mobile device dengan sistem operasi Android di masyarakat saat ini. (3) Analisa Terhadap Data dan Permainan Sejenis. Data-data dan informasi-informasi yang diperoleh setelah dikumpulkan akan dianalisa lebih lanjut untuk menetapkan kebutuhan-kebutuhan bagi sistem aplikasi permainan yang akan dikembangkan. Selain itu pada penelitian ini juga menganalisa beberapa permainan yang sejenis sebagai perbandingan, dengan harapan dapat mengembangkan aplikasi permainan yang lebih menarik daripada yang sudah ada.

Sedangkan metode untuk perancangan aplikasi adalah sebagai berikut: (1) Analisa Kebutuhan Sistem. Menentukan kebutuhan-kebutuhan sistem berdasarkan data-data yang sudah diperoleh, tujuan, dan kemampuan yang dimiliki. (2) Pertimbangan Design. Langkah dimana dilakukan beberapa perancangan mengenai struktur aplikasi, seperti perancangan layar dan antarmuka. (3) Implementasi \& Evaluasi. Hasil dari perancangan dan analisis dibangun dalam bentuk kode. Selanjutnya aplikasi permainan yang sudah selesai akan dievaluasi, apakah sesuai dengan sasaran dan rancangan, dan perlu tidaknya dilakukan penambahan fitur.

\section{HASIL DAN PEMBAHASAN}

\section{Analisa Terhadap Data \& Permainan Sejenis}

Untuk dapat merancang permainan yang dapat diterima oleh khalayak ramai, maka peneliti melakukan survei dengan menggunakan kuisioner yang bertujuan untuk melihat tren jenis permainan yang disukai di Indonesia. Dari sebanyak 102 responden terdapat 73 laki-laki (71.57\%), 79 berprofesi sebagai mahasiswa (77.45\%), 90 berumur lebih dari 19 tahun (88.24\%) menyatakan bahwa sebanyak 62 orang (35.63\%) dan 49 orang (28.16\%) menggunakan smartphone mereka untuk bermain. Sebanyak masing-masing 58 orang (15.98\%) menyukai game berjenis strategy dan RPG, dan sebanyak 88 orang (31.09\%) menyatakan bahwa komponen terpenting dalam sebuah game adalah game play. Pengisi kuisioner lebih banyak yang menyukai era ancient sebagai era dari tema perperangan dengan persentase $26.32 \%$ (55 orang).

Selanjutnya peneliti mengadakan analisa permainan yang sejenis untuk melihat kekurangan yang ada untuk dapat ditingkatkan lagi. Detail analisa permainan dapat dilihat pada tabel 6. 


\section{Perancangan Game}

\section{Game Story Design}

Permainan mengisahkan perjuangan bangsa Israel melarikan diri dari Mesir. Saat bangsa Israel menjadi budak di Mesir setelah sekian lama, di bawah pimpinan Musa, bangsa Israel berusaha melarikan diri dari Mesir, dimulai dengan menuju Kanaan terlebih dahulu. Tidak hanya dipimpin oleh Musa, setelah itu bangsa Israel dipimpin oleh Yosua, yaitu seseorang yang menjadi penerus Musa untuk membebaskan bangsa Israel. Setelah bangsa Israel keluar dari Mesir pun mereka masih harus berjuang dari serangan bangsa Filistin. Pemain memerankan salah seorang dari tokoh-tokoh yang ada dan berusaha menyelesaikan setiap misi.

\section{Game Character Design}

Tabel 3 menjelaskan detail mengenai design karakter yang dapat dimainkan pada game serta senjata dan keahlian khusus masing-masing. Terdapat tiga karakter yang dapat dimainkan pada game ini, setiap karakter memiliki senjatanya masing-masing yang dapat di-upgrade selama permainan.

Tabel 3 Character Design

\begin{tabular}{|c|c|c|c|c|}
\hline Nama & Gambar & Keterangan & Senjata & Keahlian \\
\hline Moses & & $\begin{array}{l}\text { Merupakan karakter pertama yang bisa } \\
\text { dimainkan oleh pemain. Memiliki ciri- } \\
\text { ciri fisik berambut panjang dan } \\
\text { berjanggut. Berwibawa namun kurang } \\
\text { tegas. }\end{array}$ & Tongkat & $\begin{array}{l}\text { Melakukan serangan } \\
\text { semburan api menggunakan } \\
\text { tongkatnya. }\end{array}$ \\
\hline Joshua & & $\begin{array}{l}\text { Karakter kedua setelah Moses yang akan } \\
\text { dimainkan oleh pemain setelah memasuki } \\
\text { Stage } 2 \text {. Berperawakan sedang, kurus, } \\
\text { dan gesit }\end{array}$ & Padang & $\begin{array}{l}\text { Melakukan serangan } \\
\text { melingkar dengan } \\
\text { menggunakan pedangnya } \\
\text { namun dengan rentang jarak } \\
\text { yang pendek }\end{array}$ \\
\hline David & 90 & $\begin{array}{l}\text { Karakter ketiga yang dapat dimainkan } \\
\text { setelah Moses dan Joshua. David } \\
\text { bertubuh kecil dan terlihat lemah, namun } \\
\text { memiliki kekuatan yang luar biasa. }\end{array}$ & Pedang & $\begin{array}{l}\text { Menembakkan } 5 \text { batu ke atas } \\
\text { sekaligus. Batu akan jatuh di } \\
\text { posisi yang ditentukan secara } \\
\text { acak dan musuh terdekat akan } \\
\text { terkena damage. }\end{array}$ \\
\hline
\end{tabular}

\section{Game Level Design}

Permainan memiliki alur misi linear, di mana pemain harus menyelesaikan misi secara bertahap. Terdapat tiga karakter yang akan dimainkan oleh pemain. Setiap karakter memiliki misi yang berbeda-beda. Namun memungkinkan juga pemain untuk menggunakan karakter yang sudah pernah dimainkan, sesuai pilihan pemain pada misi yang sudah diselesaikan. Permainan terdiri dari 6 level atau 6 Stage. Terdiri dari tiga karakter utama yang di mana masing-masing karakter terdiri dari 2 Stage. Karakter utama dalam setiap Stage tidak selalu sama.

Stage 1: Di Stage pertama menceritakan Moses yang mulai memberontak terhadap Mesir. Moses menyadari bahwa bangsanya sangat menderita dijadikan budak bagi orang Mesir. Ia ingin membebaskan bangsa Israel dari perbudakan bangsa Mesir. Di tahap ini, Moses berusaha membebaskan bangsa-bangsa Israel yang masih menjadi tahanan. 
Latar battle map $\quad$ : Padang pasir terdapat piramida, pepohonan, tenda, dan hewan unta.

Aturan permainan $\quad$ : Di Stage 1 saat Moses akan membebaskan bangsa Israel, terdapat 5 lokasi(berupa sebuah node) dapat terlihat dari battlemap, dan di setiap lokasi nya terdapat pasukan prajurit Mesir yang harus dilawan oleh Moses untuk dapat membebaskan para bangsa Israel. Stage 1 dimenangkan jika Moses sudah mengalahkan para prajurit Mesir di seluruh 5 lokasi tersebut. Stage 1 gagal jika Moses dikalahkan oleh para prajurit Mesir.

Stage 2: Pada Stage ini menceritakan saat Moses telah berhasil membebaskan bangsa Israel dari tahanan para prajurit Israel. Moses memimpin bangsa Israel keluar dari Mesir menuju Kanaan, tanah yang dijanjikan, melewati Laut Merah. Namun dalam perjalanannya Moses dan bangsa Israel terus dikejar oleh para prajurit Mesir.

Latar battle map $\quad$ : padang pasir terdapat gerbang keluar kota Mesir yang terbuat dari batu, pepohonan, hewan unta, tenda, dan Laut Merah

Aturan permainan $\quad$ : Di Stage 2 Moses harus membawa Bangsa Israel menuju laut merah untuk bebas dari para pajurit Mesir. Titik awalnya merupakan gerbang keluar kota Mesir dan titik tujuannya adalah Laut Merah. Saat perjalanan terdapat halangan yaitu para prajurit Mesir yang harus dilawan dan dikalahkan.

Stage 3: Menceritakan saat bangsa Israel yang telah keluar dari Mesir. Saat itu mereka sedang melakukan perjalanan ke tanah perjanjian, namun saat berkemah mereka diserang oleh bangsa Amalekhi. Joshua menjadi pemimpin dalam pertempuran ini. Melihat potensi dan kemampuan Joshua, Moses pun mengangkat Joshua untuk menjadi pemimpin bangsa Israel.

Latar battle map : : Padang gersang, terdapat bebatuan dan semak-semak, kemah-kemah bangsa Israel dan hewan unta.

Aturan permainan : Bangsa Amalekhi menyerang perkemahan bangsa Israel mereka melakukan serangan secara beramai-ramai. Terdapat 8 kelompok besar bangsa Amalekhi untuk dapat memenangkan Stage ini pemain harus dapat mengalahkan 5 kelompok besar dari 8 kelompok besar.

Stage 4: Bangsa Israel telah tiba di tanah perjanjian. Joshua sebagai pemimpin bangsa Israel harus merebut dan meruntuhkan benteng Jericho terlebih dahulu.

Latar battle map $\quad$ : Sebuah benteng besar di tengah padang berbatu dengan sedikit pohonpohon.

Aturan permainan : Pada Stage ini, Joshuan harus menyerang 7 titik utama yang menjadi kelemahan benteng Jericho. Untuk dapat menghancurkan benteng Jericho tersebut, ia harus mencari 7 titik utama dan menghancurkannya. Namun di setiap titik tersebut terdapat sejumlah besar musuh-musuh. 
Stage 5: menceritakan seorang pemuda, yaitu David yang ditugaskan oleh Raja Saul untuk berperang melawan bangsa Filistin yang dipimpin oleh Goliath.

Latar battle map $\quad$ : Benteng Israel, pohon-pohon di padang berbatu

Aturan permainan $\quad$ : Mengalahkan setiap pasukan di bawah pimpinan Goliat. Terdapat 13 pasukan penjaga yang harus dikalahkan terlebih dahulu baru Goliat dapat diserang dan kemudian dikalahkan.

Stage 6: Mengisahkan konflik antara Raja Saul dengan David. Raja Saul merasa takut kalau David akan merebut kerjaannya dan tahtanya. David pun harus lari dari Israel, saat David lari dari Israel, Raja Saul dan anaknya Jonathan berperang melawan bangsa Filistin di gunung Gilboa, dan mereka kalah dalam perperangan tersebut. David pun segera kembali ke Israel dan membantu bangsa Israel melawan bangsa Filistin. Setelah memenangkan perperangan, David pun diangkat menjadi raja menggantikan Saul karena prestasinya.

Latar battle map : Perkotaan di Israel, bangunan-bangunan dari batu baik yang utuh maupun masih dalam tahap pembangunan.

Aturan permainan : Untuk memenangkan Stage ini David harus mengalahkan semua musuh yaitu bangsa Filistin yang ada.

\section{Use Case}

Untuk memudahkan peneliti serta pembaca untuk melihat keseluruhan sistem permainan ini, maka peneliti menggunakan UML sebagai bahasa pemodelan objek standar yang diperkenalkan oleh Booch, Rumbaugh \& Jacobson (1994). Pada paper ini, hanya Use Case Diagram serta Class Diagram yang dicantumkan. Use Case Diagram menggambarkan mengenai interaksi antara sistem permainan, sistem permainan secara eksternal dan pengguna/pemain (lihat gambar 1).

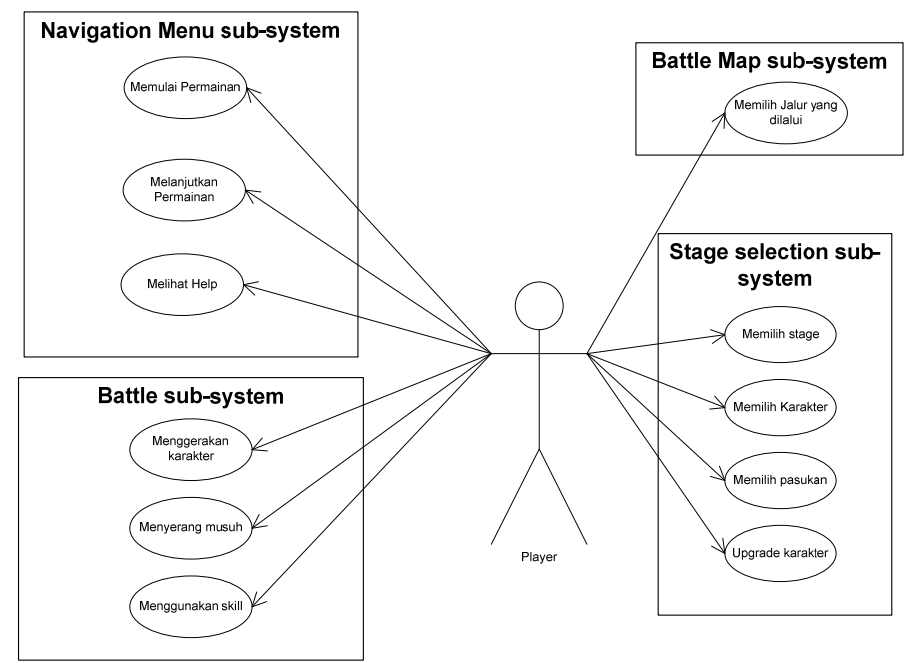

Gambar 1 Use Case Permainan

Class Diagram permainan menggambarkan struktur objek sistem permainan. Diagram ini menunjukan kelas objek yang menyusun sistem permainan dan hubungan antar kelas objek tersebut (lihat gambar 2). 


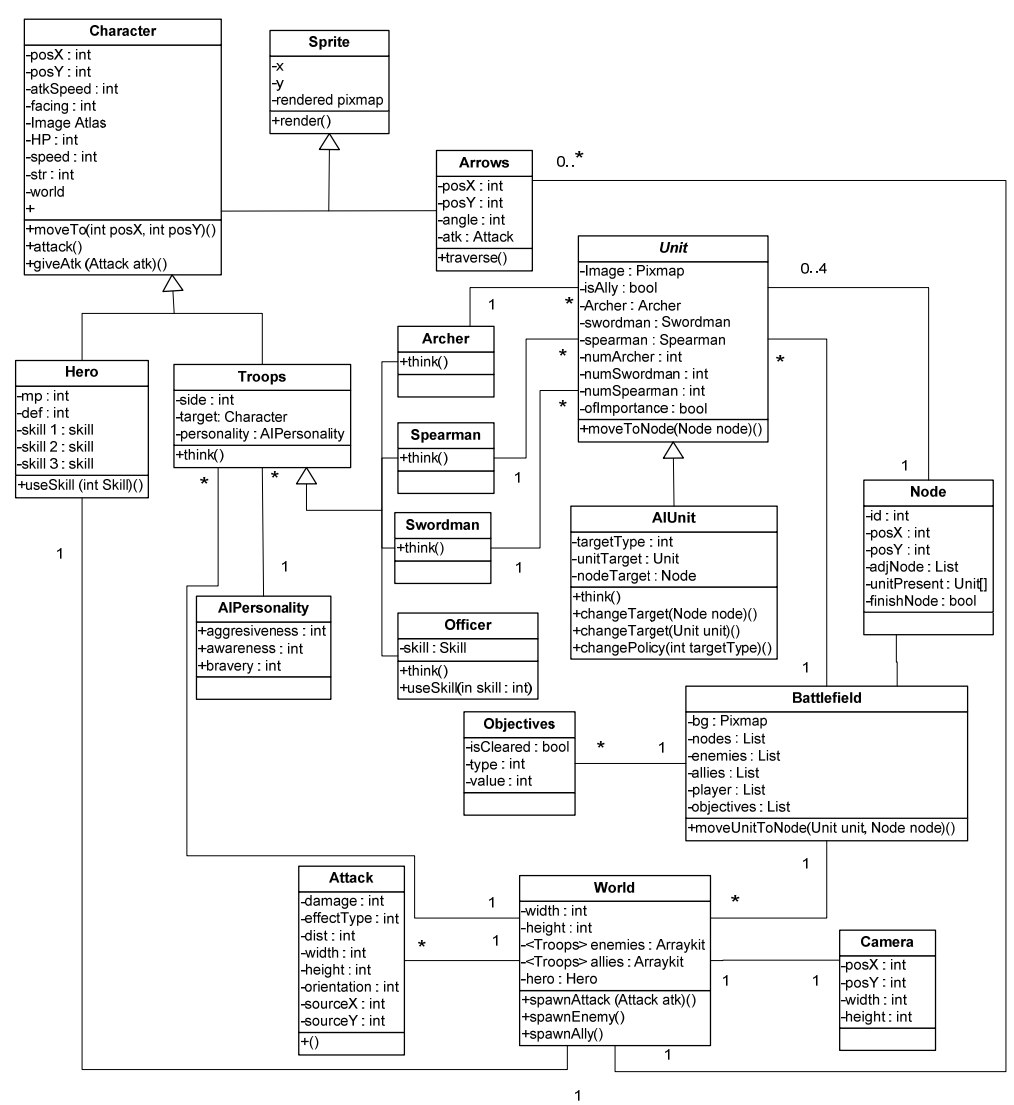

Gambar 2 Class Diagram Permainan

\section{Game Balancing}

Menurut Schell (2008) game balancing atau menyeimbangkan game tidak lebih dari mengatur elemen-elemen dalam sebuah game sampai mereka memberikan pengalaman yang diinginkan. Yang membuat sebuah game sulit untuk diseimbangkan adalah banyaknya faktor-faktor yang harus diseimbangkan. Game balancing yang dilakukan pada penelitian ini adalah Status Class Pasukan, Status Hero dan Perhitungan Damage.

\section{Status Class Pasukan}

Dalam game ini, dalam satu pasukan ada beberapa class pasukan, yaitu Swordman, Archer, dan Spearman. Masing-masing memiliki kelebihan dan kekurangannya. Swordman adalah pasukan dengan senjata pedang yang memiliki kecepatan gerak dan serang yang tinggi. Archer adalah pemanah yang menyerang dari jauh karena pertahanannya lemah. Spearman adalah pasukan dengan kekuatan besar namun memiliki gerakan yang lambat akibat besarnya senjata mereka. Pembagian kelebihan dan kekurangannya adalah menggunakan sistem poin untuk menyeimbangkan tiap class (lihat tabel 4).

Tabel 4 Class Pasukan

\begin{tabular}{llccc}
\hline Army & \multicolumn{1}{c}{ Status } & Swordman & Archer & Spearman \\
\hline \multirow{4}{*}{ Status Multiplier } & Str & 2 & 2 & 3 \\
& Def & 2 & 1 & 3 \\
& Spd & 2 & 0.5 & 1 \\
& Range & 2 & 5 & 3 \\
& Kill Prize & 2 & 1 & 3 \\
\hline
\end{tabular}


Dalam game ini, setiap Mission akan memiliki tipe pasukan yang berbeda. Pasukan adalah kumpulan dari prajurit - prajurit dari berbagai class. Setiap tipe pasukan memiliki status yang berbeda. Status dasar dari suatu pasukan disebut Base Status. Untuk menentukan status dari tiap class pada setiap pasukan, dilakukan perhitungan menggunakan rumus (1).

Class Status $=$ Base Status $*$ Multtplter

\section{Status Hero}

Dalam game ini, ada 3 karakter yang dapat dipilih oleh pemain. Masing-masing hero memiliki keunggulannya sendiri-sendiri. Moses memiliki serangan yang kuat namun gerakannya lambat. Joshua memiliki kecepatan yang tinggi untuk mengatasi pertahanannya yang lemah. David memiliki serangan yang kuat, namun pertahanan yang dimilikinya lemah. Status hero dapat diperkuat dengan menu upgrade dan membayar sejumlah gold (lihat tabel 5).

Tabel 5 Status Hero

\begin{tabular}{|c|c|c|c|c|c|c|c|c|c|c|c|c|}
\hline \multirow{2}{*}{ Hero } & \multirow{2}{*}{ Status } & \multicolumn{11}{|c|}{ Upgrade Lv. } \\
\hline & & 0 & 1 & 2 & 3 & 4 & 5 & 6 & 7 & 8 & 9 & 10 \\
\hline \multirow{3}{*}{ Moses } & Str & 50 & 55 & 65 & 75 & 90 & 110 & 135 & 175 & 200 & 240 & 300 \\
\hline & Def & 40 & 45 & 50 & 55 & 65 & 80 & 100 & 120 & 155 & 190 & 240 \\
\hline & Spd & 70 & 80 & 90 & 100 & 110 & 120 & 130 & 140 & 150 & 160 & 170 \\
\hline \multirow{3}{*}{ Joshua } & Str & 40 & 50 & 60 & 70 & 80 & 90 & 110 & 140 & 170 & 200 & 240 \\
\hline & Def & 30 & 35 & 40 & 50 & 65 & 75 & 95 & 115 & 135 & 155 & 180 \\
\hline & Spd & 90 & 100 & 110 & 120 & 130 & 140 & 150 & 160 & 170 & 180 & 190 \\
\hline \multirow{3}{*}{ David } & Str & 50 & 55 & 65 & 80 & 95 & 115 & 140 & 180 & 220 & 260 & 300 \\
\hline & Def & 30 & 35 & 45 & 55 & 65 & 80 & 100 & 120 & 140 & 160 & 180 \\
\hline & Spd & 80 & 90 & 100 & 110 & 120 & 130 & 140 & 150 & 160 & 170 & 180 \\
\hline
\end{tabular}

Status Hero memiliki total poin yang sama untuk menciptakan keseimbangan. Perkembangan status tiap hero sengaja dibuat berbeda dan memiliki variasi sendiri. Hal ini dimaksudkan untuk memberi keunikan bagi setiap Hero. Selain itu perkembangan Hero juga didistribusikan berdasarkan tingkat kesulitan misi di mana Hero tersebut pertama digunakan. Selain 3 status di atas, setiap karakter juga memiliki Health Point, yaitu yang menentukan apakah pemain masih hidup atau sudah kalah. Untuk Health Point ini, setiap karakter memiliki nilai maksimal yang sama yaitu 1000 dan tidak dapat bertambah. Ketika Health Point pemain habis, maka pemain dianggap kalah dan permainan selesai.

\section{Perhitungan Damage}

Dalam game, damage diperlukan untuk mengurangi nyawa lawan maupun kawan dan pemain. Untuk menghitung damage dalam game ini, digunakan rumus (2).

$$
\text { Damage }=\left(\frac{(\text { AttackPenyerang } * 3)-\text { DefenseTarget }}{2}\right) * 80 \% \sim 120 \%
$$

Rumus (2) berlaku untuk pemain dan juga musuh. Dengan menggunakan fungsi random, perhitungan damage muncul akan menjadi acak dan tidak tetap. Apabila hasil dari perhitungan damage adalah nilai 0 atau negatif, maka damage akan dihitung sebagai 1 . Apabila ketika diserang musuh pemain menahan tombol guard, maka damage yang diterima pemain hanya $40 \%$ dari total damage yang seharusnya diterima player. Dalam perancangan status hero dan pasukan, perhitungan damage sudah diikutsertakan. Status yang telah ditetapkan diperkirakan akan memberikan damage 
yang stabil, sehingga musuh dapat dikalahkan dengan jumlah serangan yang tidak terlalu banyak dan tidak terlalu sedikit dan pemain dapat bertahan dari serangan yang cukup banyak.

\section{Implementation}

Aplikasi permainan ini tidak memerlukan perangkat lunak khusus untuk dapat memainkannya. Untuk kebutuhan perangkat keras, diperlukan: Perangkat keras dengan sistem operasi Android, Memiliki fitur multi-touch serta ukuran layar terbaik adalah 480x320px. Testing permainan ini menggunakan Samsung Galaxy Mini. Gambar 3-5 menunjukkan hasil screen shot dari permainan ini.
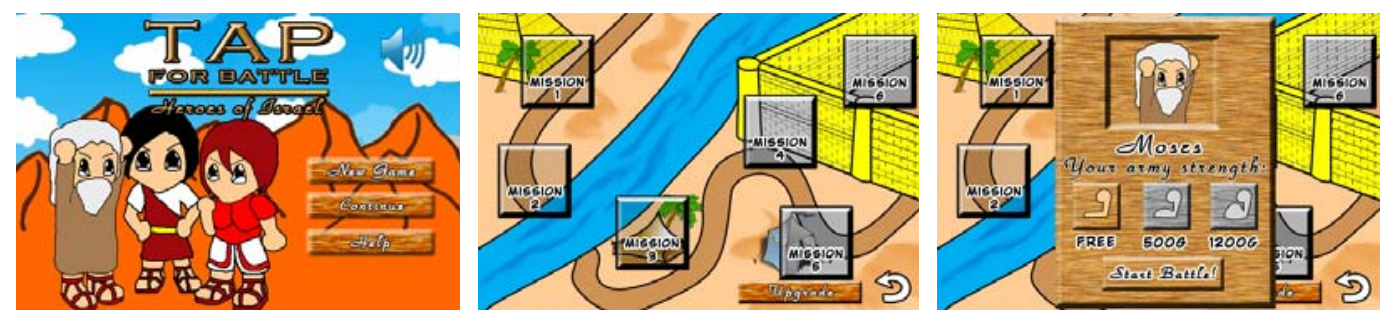

Gambar 3 Gambar Permainan (Dari kiri ke kanan, Menu utama, Menu misi, Menu pilih pemain)

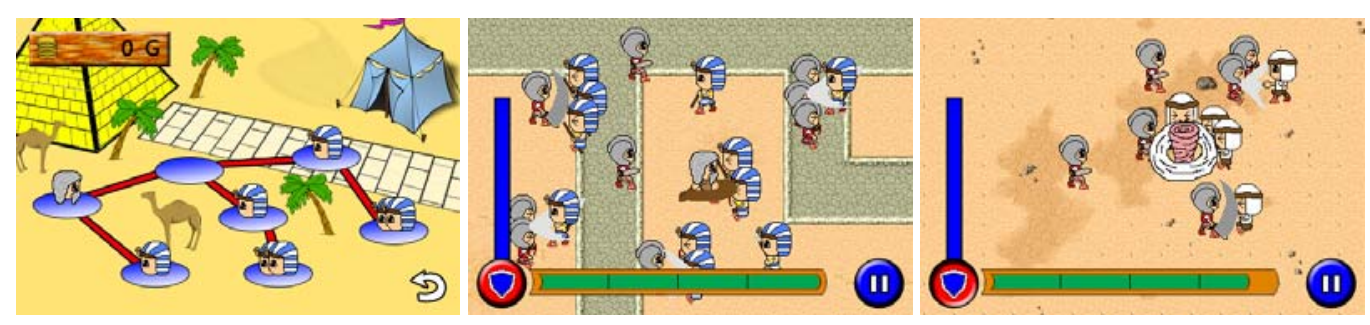

Gambar 4 Layar Permainan (Dari kiri ke kanan, Pilih musuh, Layar permainan, Special Skill)
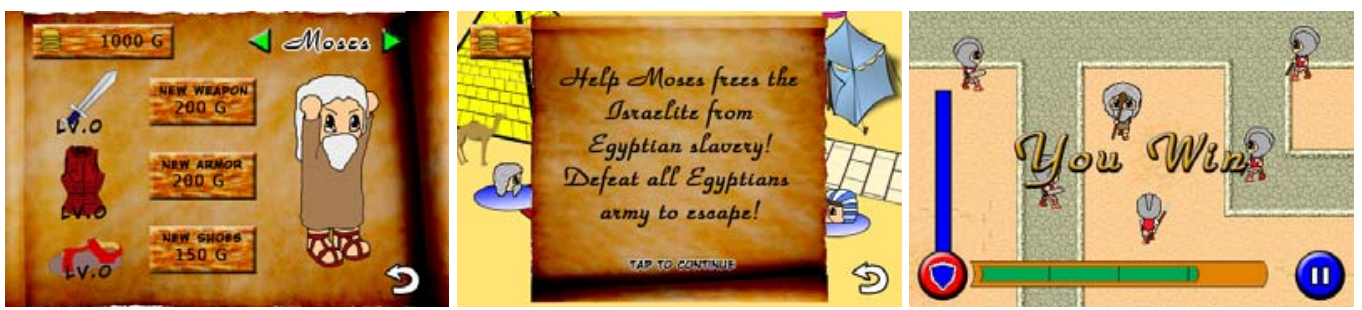

Gambar 5 Layar Informasi (Dari kiri ke kanan, Menu Upgrade, Menu informasi, Tampilan menang)

\section{Evaluasi}

Tahap terakhir dari penelitian ini adalah tahap evaluasi. Pada tahap ini, dipilih dua metode untuk evaluasi. Pertama peneliti kembali melakukan perbandingan terhadap game yang sejenis yang sebelumnya sudah dilakukan di tahap Analisa Terhadap Data \& Permainan Sejenis. Kemudian, dilakukan evaluasi pengguna dengan menggunakan kuisioner. Evaluasi dengan perbandingan terhadap game sejenis dapat dilihat pada tabel 6 . 
Tabel 6 Evaluasi Perbandingan terhadap game sejenis

\begin{tabular}{|c|c|c|c|c|}
\hline & $\begin{array}{c}\text { Lord of the Rings : } \\
\text { Conquest }\end{array}$ & $\begin{array}{c}\text { Dynasty Warriors } \\
\text { Advance }\end{array}$ & Guns and Glory & $\begin{array}{c}\text { Tap For Battle: Heroes } \\
\text { of Israel }\end{array}$ \\
\hline Tipe Permainan & Action / Hack and Slash & Action / Hack and Slash & $\begin{array}{l}\text { Action/Shooting } \\
\text { Game }\end{array}$ & Casual/Action \\
\hline Grafik & Kurang baik & $\begin{array}{l}\text { Kurang, grafik } \\
\text { berbentuk pixel }\end{array}$ & $\begin{array}{l}\text { Sangat bagus, } \\
\text { menarik }\end{array}$ & Cukup bagus, menarik \\
\hline Tipe Grafik & $3 \mathrm{D}$ & $2 \mathrm{D}$ & 2D & $2 \mathrm{D}$ \\
\hline Game Play & 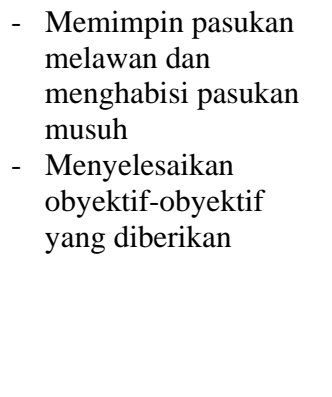 & $\begin{array}{l}\text { - Secara berganti- } \\
\text { gantian dengan } \\
\text { musuh dan kawan } \\
\text { menentukan gerak } \\
\text { pasukan dalam } \\
\text { medan perang } \\
\text { - Secara real-time } \\
\text { melawan pasukan } \\
\text { musuh sendirian }\end{array}$ & $\begin{array}{l}\text { - } \text { Berperan sebagai } \\
\text { Bandit yang } \\
\text { berusaha } \\
\text { menembaki } \\
\text { warga yang akan } \\
\text { melewati } \\
\text { perbatasan } \\
\text { - Mengatur } \\
\text { keseimbangan } \\
\text { dalam permainan. }\end{array}$ & 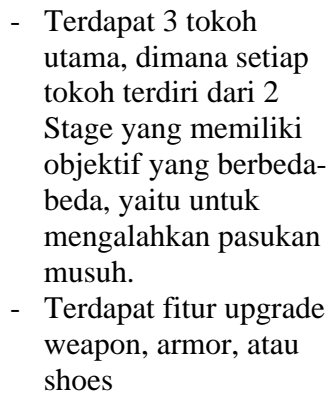 \\
\hline $\begin{array}{l}\text { Tingkat Level } \\
\text { Kesulitan }\end{array}$ & $\begin{array}{l}\text { - Seiring bertambahnya } \\
\text { medan perang yang } \\
\text { bisa dimainkan, } \\
\text { obyektif-obyektif } \\
\text { yang diberikan } \\
\text { menjadi lebih rumit } \\
\text { dan sulit }\end{array}$ & $\begin{array}{l}\text { - Seiring jalanya cerita } \\
\text { dan medan perang } \\
\text { yang baru, musuh- } \\
\text { musuh akan menjadi } \\
\text { lebih tangguh dan } \\
\text { sulit dihadapi }\end{array}$ & $\begin{array}{l}\text { - Seiring kenaikan } \\
\text { level }\end{array}$ & $\begin{array}{l}\text { - Pada setiap tokoh } \\
\text { terdiri dari } 2 \text { Stage } \\
\text { dimana Stage pertama } \\
\text { memiliki tingkat level } \\
\text { kesulitan yang lebih } \\
\text { mudah dibandingkan } \\
\text { Stage keduanya }\end{array}$ \\
\hline $\begin{array}{l}\text { Puncak Tingkat } \\
\text { Kejenuhan }\end{array}$ & $\begin{array}{l}\text { - Saat seluruh cerita } \\
\text { sudah diselesaikan } \\
\text { - Saat pemain } \\
\text { menguasai teknik } \\
\text { repetitif yang } \\
\text { memungkinkan } \\
\text { musuh dikalahkan } \\
\text { tanpa melukai } \\
\text { karakter pemain } \\
\text { - Gameplay } \\
\text { peperangan yang } \\
\text { repetitif, diselingi } \\
\text { obyektif }\end{array}$ & $\begin{array}{l}\text { - Saat pemain sudah } \\
\text { memperoleh semua } \\
\text { senjata masing- } \\
\text { masing karakter dan } \\
\text { menyelesaikan } \\
\text { ceritanya. } \\
\text { - Pemain harus melalui } \\
\text { pertarungan dengan } \\
\text { musuh yang sama } \\
\text { berulang-ulang untuk } \\
\text { menyelesaikan satu } \\
\text { level }\end{array}$ & $\begin{array}{l}\text { - Saat pemain } \\
\text { sudah } \\
\text { menyelesaikan } \\
\text { semua level }\end{array}$ & $\begin{array}{l}\text { - Saat telah } \\
\text { menyelesaikan semua } \\
\text { mission }\end{array}$ \\
\hline Update Stage & Tidak ada & Tidak ada & Tidak ada & Tidak ada \\
\hline Kontrol & Touchscreen, Keypad & Keypad & Touchscreen & Touchscreen \\
\hline $\begin{array}{l}\text { Penggunaan } \\
\text { Touchscreen }\end{array}$ & $\begin{array}{l}\text { Ya, sebagai kontrol } \\
\text { utama }\end{array}$ & Tidak & Ya & $\begin{array}{l}\text { Ya, sebagai kontrol } \\
\text { utama }\end{array}$ \\
\hline $\begin{array}{l}\text { Penggunaan } \\
\text { Fitur Multi- } \\
\text { Touch }\end{array}$ & Tidak & Tidak & $\mathrm{Ya}$ & $\mathrm{Ya}$ \\
\hline
\end{tabular}

\section{Evaluasi Kuesioner}

Evaluasi ini dilakukan demi mendapat masukan untuk perbaikan dan pengembangan selanjutnya. Evaluasi dilakukan melalui penyebaran kuesioner kepada 31 orang (22 laki laki, 28 berumur lebih dari 19 tahun) yang telah mencoba permainan ini. Hasil dari kuisioner dapat dilihat pada tabel 7 serta gambar 6 . Nilai 3 berarti baik, 2 lumayan, serta 1 berarti buruk. 
Tabel 7 Hasil Evaluasi Pengguna

\begin{tabular}{lccc}
\hline Komponen & $\mathbf{3}$ & $\mathbf{2}$ & $\mathbf{1}$ \\
\hline Tema & 22 & 8 & 1 \\
gameplay & 18 & 22 & 1 \\
Tingkat kesulitan & 4 & 22 & 5 \\
Grafik & 7 & 21 & 3 \\
Music & 10 & 21 & 0 \\
Sound Effect & 10 & 21 & 0 \\
Tutorial & 29 & 2 & 0 \\
Touch Screen & 26 & 5 & 0 \\
\hline
\end{tabular}

\section{SIMPULAN}

Berdasakan hasil analisa, pembahasan dan evaluasi (lihat gambar 6 dan tabel 7), maka diperoleh beberapa kesimpulan bahwa tema dari permainan ini cukup diminati oleh pengguna, sebanyak $70.97 \%$ pengguna memiliki score yang baik untuk tema peperangan. Pengguna juga menyatakan bahwa game play dari game menarik, namun cukup mudah untuk dimainkan. Berdasarkan hasil kuesioner evaluasi, grafik pada game sudah cukup bagus. Penggunaan background music dan sound effect sudah cukup sesuai. Serta juga setting dari game sudah cocok serta evaluasi dan tutorial yang tersedia memudahkan untuk mempelajari kontrol dari game.

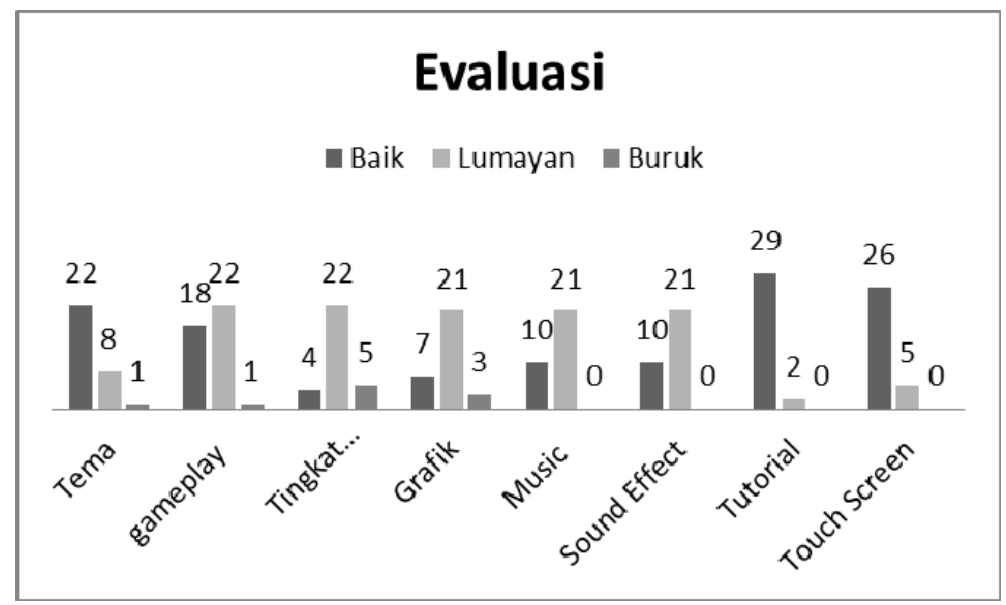

Gambar 6 Hasil Evaluasi Pengguna 


\section{DAFTAR PUSTAKA}

Booch, G., Rumbaugh, J., Jacobson, I. (1994). The Unified Modeling Language User Guide (2nd Edition). Addison-Wesley Professional

Chowanda, A., Prasetio Y. L. (2012). Perancangan Game Edukasi Bertemakan Sejarah. Proceedings SEMANTICS , 151-155. BINUS Uiversity, Jakarta: Computer Science Department, School of Computer Science, BINUS University

Chowanda, A. (2011). Perancangan Game Kartu interaktif berbasis android Menggunakan Augmented Reality. ComTech, 2 (2), 726-735.

- (2013). EMOWARS: INTERACTIVE GAME INPUT MENGGUNAKAN EKSPRESI WAJAH. ComTech, 4(2), 1009-1017.

(2011). ANALISIS DAN PERANCANGAN GAME EDUKASI ONLINE. Seminar Nasional Binus ICTC 2011, 566-571. BINUS University, Jakarta: Fakultas Ilmu Komputer, Universitas Bina Nusantara

Dastbaz, M. (2002). Designing Interactive Multimedia Systems. McGraw-Hill Education.

IDC Worldwide Quarterly Mobile Phone Tracker. (2014) Smartphone OS Market Share, Q1 2014. Diakses pada 25 Mei 2014, dari http://www.idc.com/prodserv/smartphone-os-marketshare.jsp.

Jesse Schell. 2008. The Art of Game Design: A Book of Lenses. San Francisco, CA, USA: Morgan Kaufmann Publishers Inc.

Rosson, M. B., Carroll, J. M. (2002a). Scenario-based design. In The human-computer interaction handbook, Julie A. Jacko and Andrew Sears (Eds.). Hillsdale, NJ, USA 1032-1050: L. Erlbaum Associates Inc.

Rosson, M. B., Carroll, J. M. (2002b). Usability Engineering: Scenario-based Development of Human-computer Interaction. Morgan Kaufmann series in interactive technologies. Morgan Kaufmann. 